\title{
Abbreviations Used in the Footnotes
}

BQ William C. Braithwaite, The Beginnings of Quakerism (Cambridge, 1955)

Besse Joseph Besse, A Collection of the Sufferings of the People Called Quakers (London, 1753)

DBR Biographical Dictionary of British Radicals in the Seventeenth Century, ed. Richard L. Greaves and Robert Zaller (Brighton, 1982-84)

DQB Dictionary of Quaker Biography, typescript, Haverford College Library and Library of the Society of Friends, London

EQW Early Quaker Writings, 1650-1700, ed. Hugh Barbour and Arthur O. Roberts (Grand Rapids, 1973)

FL The Friends Library (Philadelphia, 1842)

FPT The First Publishers of Truth, ed. Norman Penney (London, 1907)

GBS Great Book of Sufferings, MS, Library of the Society of Friends, London

JFHS Journal of the Friends Historical Society

PP Piety Promoted, in a Collection of Dying Sayings of Many of the People Called Quakers, 4 vols. (Philadelphia, 1854) 
PWP The Papers of William Penn, ed. Mary Maples Dunn and Richard S. Dunn (Philadelphia, 1981-)

QH Quaker History

QPE Hugh Barbour, The Quakers in Puritan England (New Haven and London, 1964)

SM Swarthmore Manuscripts

SPQ William C. Braithwaite, The Second Period of Quakerism (York, 1979) 